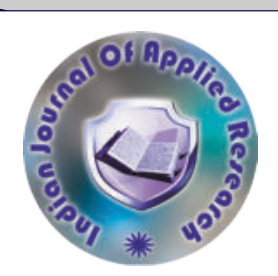

Nursing Science

\title{
IMPACT OF SELF-INSTRUCTIONAL MODULE ON PERCEPTION REGARDING CATHETER RELATED BLOOD STREAM INFECTIONS AMONG NURSING OFFICERS IN SELECTED HOSPITALS OF MADHYA PRADESH
}

\author{
MS. Asha Dubey* Ph.D. Scholar, JJTU University, Jhunjhunu (Rajasthan)*Corresponding Author \\ Dr. Rajni Thakur Research Guide, Vice principal, SAIMS College of Nursing, Indore M.P.
}

ABSTRACT Infections associated with intravascular catheters account for $10 \%$ to $20 \%$ of all nosocomial infections. HealthcareABSTRACT associated infections are a significant problem and $20-40$ percent of healthcare-associated bloodstream infections may be linked to a central venous catheter. This infection is referred to as central line associated bacteremia.

At posttest stage, the average (Mean \pm Standard Deviation) perception scoring (38.04 \pm 5.75 points) among nursing officers of experimental group found to be significantly higher and improved after administration of self-instructional module as compared to average perception scoring (29.47 \pm 6.23 points) of nursing officers of control group who received placebo.

KEYWORDS : Self Instructional Module, Perception, Nursing Officers, Central line associated bloodstream infection (clabsi) INTRODUCTION

A CLABSI is a primary bloodstream infection that is, there is no apparent infection at another site) that develops in a patient with a central line and many other venous catheters etc. in place within the 48 hour period before onset of the bloodstream infection that is not related to infection at another site. Culturing the catheter tip or peripheral blood is not a criterion for CLABSI.

CLABSI is a more rigorous diagnostic definition and requires specific laboratory testing to identify the catheter as the source of the bloodstream infection, such as culturing the catheter tip or a more elaborate method such as differential time-to-positivity of blood cultures. Employing relatively simple evidence-based practices to reduce, if not eliminate, CLABSIs appears to be within the reach of even resource-limited settings. Within this framework, HAIs - and CLABSIs in particular - are more and more being viewed as "preventable events".

\section{Review of Literature}

Susan Elizabeth McKenna (2018), in her work entitled : Assessment of Nurse Behaviors that Influence Care and Maintenance of Pediatric Oncology Central Venous Catheters, was experimented to gain an understanding of perceptions of CLABSI prevention, observe adherence to the CLABSI prevention bundle, measure adherence to the current CLASBI prevention bundle (post-training), identify ways to improve adherence to the CLASBI bundle and ascertain potential strategies for further compliance efforts. Their findings interpreted that implementation of CLABSI infection prevention efforts inclusive of supporting the use of "champions" respondent suggestions such as lowering the nurse-patient ratio and increasing family engagement.

\section{OBJECTIVES OF THE STUDY}

1] To evaluate pre-test scores of perception regarding catheter related blood stream infections among nursing officers in Experimental and Control group.

2] To determine the impact of self-instructional module on perception regarding catheter related blood stream infections among nursing officers in Experimental and Control group.

3] To find out the association between pretest and post-test scores of perception with selected demographic variables among nursing officers in Experimental and Control group.

\section{Hypothesis}

$\mathbf{H}_{01}$ - There will be no significant difference between pre-test and post -test scores of perception regarding catheter related blood stream infections among nursing officers in Experimental and Control group. $\mathbf{H}_{\mathbf{A} 1}-$ There will be a significant difference between pre-test and post -test scores of perception regarding catheter related blood stream infections among nursing officers in Experimental and Control group. $\mathbf{H}_{02}-$ There will be no impact of self-instructional module on perception regarding catheter related blood stream infections among nursing officers in Experimental and Control group.

$\mathbf{H}_{\mathbf{A} 2}-$ There will be an impact of self-instructional module on perception regarding catheter related blood stream infections among nursing officers in Experimental and Control group.

$\mathbf{H}_{03}$ - There will be no association between pretest and post-test

perception scores with selected demographic variable among nursing officers in Experimental and Control group.

$\mathbf{H}_{\mathrm{A} 3}-$ There will be significant association between pretest and posttest perception scores with selected demographic variable among nursing officers in Experimental and Control group.

\section{METHODOLOGY-}

The research design of present research study is "Pre-test Post-test Control only /Experimental" which consists of experimental and control groups. Study set up of present research was at various nursing hospitals. Present study is carried out at selected Nursing Hospitals of Madhya Pradesh in association with Department of Nursing of Shri Jagdish Prasad Jhabarmal Tibrewala University, Vidyanagari, Jhunjhunu, (Rajasthan). Random sampling technique is used at both the stage of sampling for this study. Probability sampling technique (simple random sampling) employed at sampling stage one used to select the desired samples from the population of nursing officers. At sampling stage two, allocation of a group to a sample either for administration of self-instructional module or placebo was carried out using lottery method (simple random sampling). The researcher used a 5-point Likert scale for assessment of perception of nursing officers regarding CLABSI.

\section{RESULTS}

1. Main features and characteristics of studied nursing officers-

- Observations indicated that major part of population of nursing officers of experimental group $(172,49.1 \%)$ was most commonly belonged to age group of 20-34 years while large chunk of population of control group $(185,52.9 \%)$ was most commonly belonged to age group of 35-49 years.

- Comparison between groups revealed that major part of population of nursing officers of experimental group $(212,60.6 \%)$ and control group $(237,67.7 \%)$ were more frequently male.

- Enquiry reported that the level of education of most of the nursing officers of experimental group (183, 52.3\%) and control group $(172,49.1 \%)$ found to be B.Sc. Nursing.

- Comparison in marital statuses revealed that major part of population of nursing officers of experimental group $(230,65.7 \%)$ and control group $(255,72.9 \%)$ were more frequently married.

- Duration of duration of total working of approximately half (165, $47.1 \%$ ) of the nursing officers of experimental group found to be most commonly less than or equal to 4.0 years whereas the duration of total working of approximately of more than half (198, $56.6 \%)$ of the nursing officers of control group were most commonly found to be from 4.1 to 8.0 years

- The family incomes of most of the nursing officers of experimental group $(168,48.0 \%)$ and control group $(167,47.7 \%)$ were more frequently between $\square 15001 /$ - and $\square 20000 /-$

- Comparison revealed that large chunks of population of nursing officers of experimental group $(187,53.4 \%)$ and control group $(203,58.0 \%)$ reported with previous knowledge about catheter related blood stream infections and it had gained from various sources.

- No any source of previous knowledge about catheter related blood stream infections revealed by less than half of the nursing officers 
Volume - 11 | Issue - 01 | January - 2021 | PRINT ISSN No. 2249 - 555X | DOI : 10.36106/ijar

of experimental group $(163,46.6 \%)$ and control group (147, $42.0 \%)$

Table - 1 Main features and characteristics of studied nursing officers

\begin{tabular}{|c|c|c|c|c|}
\hline \multirow{2}{*}{$\begin{array}{c}\text { Characteristics } \\
\text { of Nursing } \\
\text { Officers }\end{array}$} & \multicolumn{2}{|c|}{ Experimental group } & \multicolumn{2}{|c|}{ Control group } \\
\hline & $\begin{array}{l}\text { Frequency } \\
\left(\mathbf{n}_{1}\right)\end{array}$ & $\begin{array}{c}\text { Percentage } \\
(\%)\end{array}$ & $\begin{array}{l}\text { Frequency } \\
\qquad\left(\mathbf{n}_{2}\right)\end{array}$ & $\begin{array}{c}\text { Percentage } \\
(\%)\end{array}$ \\
\hline \multicolumn{5}{|c|}{ According to Age } \\
\hline 20-34 year & 172 & 49.1 & 144 & 41.1 \\
\hline 35-49 year & 138 & 39.4 & 185 & 52.9 \\
\hline 50-64 year & 40 & 11.4 & 21 & 6.0 \\
\hline \multicolumn{5}{|c|}{ According to Gender } \\
\hline Male & 212 & 60.6 & 237 & 67.7 \\
\hline Female & 138 & 39.4 & 113 & 32.3 \\
\hline \multicolumn{5}{|c|}{ According to Educational Qualification } \\
\hline GNM Nursing & 143 & 40.9 & 163 & 46.6 \\
\hline B. Sc. Nursing & 183 & 52.3 & 172 & 49.1 \\
\hline M. Sc. Nursing & 24 & 6.9 & 15 & 4.3 \\
\hline \multicolumn{5}{|c|}{ According to Marital Status } \\
\hline Unmarried & 120 & 34.3 & 95 & 27.1 \\
\hline Married & 230 & 65.7 & 255 & 72.9 \\
\hline \multicolumn{5}{|c|}{ According to Total working experience } \\
\hline$\leq 4.0$ year & 165 & 47.1 & 111 & 31.7 \\
\hline 4.1-8.0 years & 144 & 41.1 & 198 & 56.6 \\
\hline 8.1-12.0 years & 11 & 3.1 & 24 & 6.9 \\
\hline$>12.0$ years & 30 & 8.6 & 17 & 4.9 \\
\hline \multicolumn{5}{|c|}{ According to Monthly Income of Family } \\
\hline $\begin{array}{l}\text { ₹10000/- to } \\
15000 /-\end{array}$ & 95 & 27.1 & 70 & 20.0 \\
\hline $\begin{array}{l}\text { ₹ } 15001 /- \text { to } \\
20000 /-\end{array}$ & 168 & 48.0 & 167 & 47.7 \\
\hline $\begin{array}{l}\text { ₹20001/- to } \\
25000 /-\end{array}$ & 61 & 17.4 & 71 & 20.3 \\
\hline$\geq ₹ 25000 /-$ & 26 & 7.4 & 42 & 12.0 \\
\hline \multicolumn{5}{|c|}{$\begin{array}{l}\text { According toprevious knowledgeabout catheter related blood } \\
\text { stream infections }\end{array}$} \\
\hline No & 163 & 46.6 & 147 & 42.0 \\
\hline Yes & 187 & 53.4 & 203 & 58.0 \\
\hline \multicolumn{5}{|c|}{ According tosource of previous knowledge } \\
\hline None & 163 & 46.6 & 147 & 42.0 \\
\hline $\begin{array}{l}\text { Educational } \\
\text { Institution }\end{array}$ & 124 & 35.4 & 162 & 46.3 \\
\hline CNE/Conferences & 27 & 7.7 & 14 & 4.0 \\
\hline Mass Media & 17 & 4.9 & 10 & 2.9 \\
\hline Print Media & 13 & 3.7 & 14 & 4.0 \\
\hline Journal/Magazine & 6 & 1.7 & 3 & 0.9 \\
\hline
\end{tabular}

Table - 2 Comparison of perception scoring between nursing officers of experimental and control groups at baseline and post intervention stages.

Difference in pre-existed perception ( 0.80 points) at baseline stage regarding catheter related blood stream infections between nursing officers of experimental and control groups found to be very small just ignorable and thus could not reached at statistically significant $(p>0.05)$ level of significance. This reflected at baseline stage that the nursing officers of two groups, experimental and control found with approximately similar statuses with respect to their pre-existed perception about catheter related blood stream infections.

At posttest stage, the average (Mean \pm Standard Deviation) perception scoring (38.04 \pm 5.75 points) among nursing officers of experimental group found to be significantly higher and improved after administration of self-instructional module as compared to average perception scoring $(29.47 \pm 6.23$ points $)$ of nursing officers of control group who received placebo. However, the large mean difference of 8.57 points in perception scoring at post intervention stage between nursing officers of experimental and control groups were statistically strongly significant $(\mathrm{p}<0.001)$.

\begin{tabular}{|c|c|c|c|c|}
\hline \multirow[t]{2}{*}{ Sampling Stage } & \multirow{2}{*}{$\begin{array}{l}\text { Group and } \\
\text { Difference }\end{array}$} & Scatter & \multirow{2}{*}{$\begin{array}{c}\text { Z-S } \\
\text { tatistic }\end{array}$} & \multirow{2}{*}{$\begin{array}{c}\text { p-value } \\
\text { (LOS) }\end{array}$} \\
\hline & & Mean \pm SD & & \\
\hline \multirow{2}{*}{\begin{tabular}{|c|}
$\begin{array}{c}\text { Baseline Perception } \\
\text { (Pre-test) }\end{array}$ \\
\end{tabular}} & Experimental & $29.71 \pm 9.60$ & \multirow[t]{2}{*}{1.32} & \multirow[t]{2}{*}{$\mathrm{p}>0.05$} \\
\hline & Control & $28.91 \pm 6.05$ & & \\
\hline NDIAI & \multicolumn{4}{|c|}{ NDIAN JOURNAL OF APPLIED RESEARCH } \\
\hline
\end{tabular}

\begin{tabular}{|c|c|c|c|c|}
\hline & $\begin{array}{c}\text { Mean } \\
\text { Difference }\end{array}$ & 0.80 points & & \\
\hline $\begin{array}{c}\text { Post-Intervention } \\
\text { Perception } \\
\text { (Post-test) }\end{array}$ & Experimental & $38.04 \pm 5.75$ & 18.91 & $\mathrm{p}<0.001$ \\
\cline { 2 - 3 } & Control & $29.47 \pm 6.23$ & & \\
\cline { 2 - 3 } & $\begin{array}{c}\text { Mean } \\
\text { Difference }\end{array}$ & 8.57 points & & \\
\hline
\end{tabular}

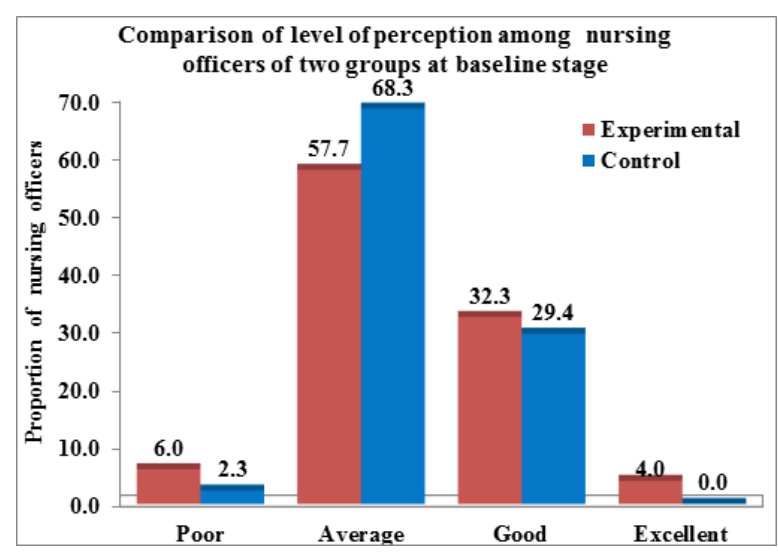

Fig - 1 -Bar diagram is presenting the comparison in perception regarding catheter related blood stream infections between nursing officers of experimental and control groups at pre administration.

\section{CONCLUSION}

Self-instructional module found to be effective tool was noticed in improving the perception regarding catheter related blood stream infections among nursing officers and further may be consider as an effective tool when there is a need in lacking, bridging and modifying the information about improvement of perception regarding catheter related blood stream infections.

\section{REFERENCES}

1. Bulbul A, Okan F, Nuhoglu A (2010) Percutaneously inserted central catheters in the newborns: a center's experience in Turkey,J MaternFetal Neonatal Med. Jun;23(6):52935 .

2. Carol Halter, Linda Buckwal, Zoraida Salas-Allison, Cathleen Murphy-Taylor (2009) Evaluating Central Venous Catheter Care in a Pediatric Intensive Care Unit. American journal of critical care Vol (18):514-520.

3. Centers for Disease Control and Prevention. Guidelines for the prevention of intravascular catheter-related infections. MMWR. (2002), 51(RR10): 11-12. Centers for Disease Control and Prevention. Intravascular Catheter-Associated Bloodstream Infections.

4. Claire Molloy (2009) Procedure for the care of central venous line exit site for children [Internet]. Solihullcare trust Available from: http://www. solihull. nhs.uk/ getmedia/ 1b42311d-6215-4a11

5. Costello JM, Morrow DF, Graham DA, Potter-Bynoe G, Sandora TJ, Lausen PC (2008) Systematic intervention to reduce central line-associated bloodstream infection rates in a pediatric cardiac intensive care unit. Pediatrics. 121(5):915-923.

6. Denis Frasca, Claire Dahyot-Fizelier, Olivier Mimoz (2010), Prevention of central venous catheter-related infection in the intensive care unit.

7. G. Fratino, A. C. Molinari, S. Parodi, S. Longo, P. Saracco, E. Castagnolaet.el. (2005) Central venous catheter-related complications in children with oncological/ hematological diseases.

8. Horvath B, Norvillie R, Lee D, Hyde A, hockenberryM, Gregurich M (2009) Reducing central venous catheter-related bloodstream infections in children with cancer;36(2):232-8.

9. J W Puntis, C E Holden, S Smallman, Y Finkel, R H George (1991) and I W Booth.Staff training: a key factor in reducing intravascular catheter sepsis. Arch Dis Child; 66(3): 335-337. 